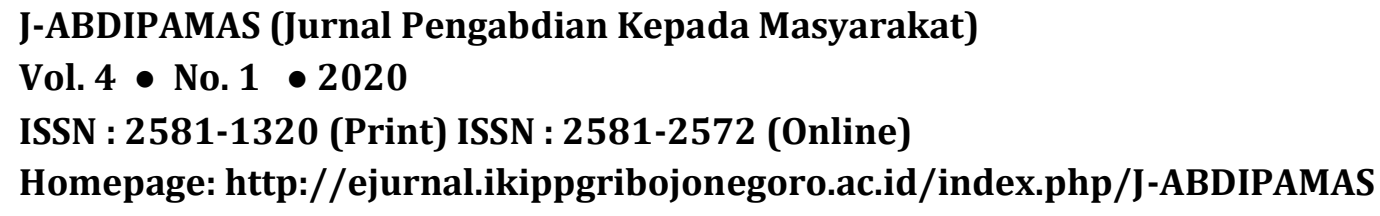

ISSN : 2581-1320 (Print) ISSN : 2581-2572 (Online)

Homepage: http://ejurnal.ikippgribojonegoro.ac.id/index.php/J-ABDIPAMAS

\title{
PENDAMPINGAN PENYUSUNAN PERANGKAT PEMBELAJARAN KURIKULUM 2013 BAGI GURU MADRASAH ALIYAH
}

\author{
Khalimatus Sadiyah ${ }^{1}$, Mahalli ${ }^{2}$, Fathur Rohman ${ }^{3}$, Azzah Nor Laila ${ }^{4}$ \\ ${ }^{1}$ Universitas Islam Nahdlatul Ulama Jepara. Email: favimillati@gmail.com \\ 2 Universitas Islam Nahdlatul Ulama Jepara. Email: elkhasya.jpr@gmail.com \\ 3 Universitas Islam Nahdlatul Ulama Jepara. Email: fathur_rohman@unisnu.ac.id \\ ${ }^{4}$ Universitas Islam Nahdlatul Ulama Jepara. Email: azzah@unisnu.ac.id
}

\begin{abstract}
The 2013 curriculum was established by the Ministry of Education and Culture in the middle of the 2013/2014 school year. But until now most of schools have not been implementing it yet. Many new aspects must be adapted by the school, such as administration, learning models, and evaluation systems. So there are still many schools were not totality to implement the 2013 curriculum. One of school that is considered still not total in implementing the 2013 curriculum is Madrasah Aliyah Walisongo Pecangaan Jepara. The contributing factors included the lack of knowledge of MA Walisongo educators in implementing the 2013 curriculum. Looking at the situation, the team of PAI Study Program of the Education Faculty and Teaching Sciences of Unisnu Jepara took the initiative to provide solutions in the form of training and mentoring in the creation of the 2013 curriculum for educators in the madrasah. The target of this training and mentoring is to increase the ability of MA Walisongo educators in preparing learning tools, including learning plans, learning designs, and learning evaluations. The method of implementing this service uses three stages. First, the training was held in two meetings to discuss the theme of the 2013 curriculum concept, syllabus \& KI-KD mapping, preparation of the RPP, and practice. Second, mentoring is carried out for four weeks after training. Third, program evaluation with Focus Group Discussion activities with MA Walisongo Pecangaan educators. The results of this service community are the 2013 curriculum learning tools including RPP and 2013 Curriculum Assessment instruments.
\end{abstract}

Keywords: Training, Mentoring, Learning device, 2013 Curriculum.

\begin{abstract}
ABSTRAK
Kurikulum 2013 ditetapkan oleh kemendikbud pada pertengahan tahun ajaran 2013/2014, akan tetapi hingga saat ini masih banyak sekolah yang belum mengimplementasikannya. Banyak aspek baru yang harus diadaptasi oleh sekolah baik dari aspek administrasi, model pembelajaran, maupun sistem evaluasi. Sehingga masih banyak sekolah atau madrasah yang menerapkan kurikulum 2013 setengah-setangah. Salah satu sekolah yang dipandang masih belum total dalam menerapkan kurikulum 2013 adalah Madrasah Aliyah Walisongo Pecangaan Jepara. Faktor penyebabnya antara lain minimnya pengetahuan pendidik MA Walisongo dalam mengimplementasikan kurikulum 2013. Melihat situasi tersebut, maka tim pengabdian Program Studi PAI Fakultas Tarbiyah dan Ilmu Keguruan Unisnu Jepara, berinisiatif memberikan solusi berupa pelatihan dan pendampingan pembuatan perangkat kurikulum 2013 untuk pendidik di madrasah tersebut. Target dari pelatihan dan pendampingan ini adalah peningkatan kemampuan pendidik MA Walisongo dalam menyusun perangkat pembelajaran, meliputi rencana pembelajaran, rancangan pembelajaran, dan evaluasi pembelajaran. Metode pelaksanaan pengabdian ini menggunakan tiga tahapan. Pertama, pelatihan dilaksanakan dalam dua kali pertemuan membahas tema konsep kurikulum 2013, Silabus dan pemetaan KI-KD, penyusunan RPP, dan praktik. Kedua, pendampingan dilakukan selama empat minggu setelah pelatihan. Ketiga, evaluasi program dengan kegiatan Focus Group Discussion bersama para pendidik MA Walisongo Pecangaan. Hasil kegiatan pengabdian ini adalah perangkat pembelajaran kurikulum 2013 meliputi RPP dan Instrumen penilaian Kurikulum 2013.
\end{abstract}

Kata Kunci: Pelatihan, Pendampingan, Perangkat pembelajaran, Kurikulum 2013 


\section{PENDAHULUAN}

Secara substansial, kurikulum dimaknai sebagai suatu rencana kegiatan belajar bagi peserta didik di suatu lembaga pendidikan, atau sebagai suatu seperangkat program untuk mencapai tujuan tertentu. Kurikulum biasanya identik dengan suatu dokumen yang berisi rumusan tentang tujuan, bahan ajar, kegiatan belajar-mengajar, jadwal, dan evaluasi yang berlaku dalam lingkup tertentu, baik tingkat sekolah, kabupaten, propinsi, ataupun seluruh negara. Ronald Doll mengemukakan bahwa kurikulum ... all the experiences which are offered to learners under the auspices or direction of the school" atau Kurikulum meliputi semua pengalaman yang harus dilalui peserta didik di bawah bantuan atau bimbingan sekolah. Singkatnya, Kurikulum adalah seperangkat rencana dan pengaturan mengenai tujuan, isi, dan bahan pelajaran serta bahan yang digunakan sebagai pedoman penyelenggaraan kegiatan pembelajaran untuk mencapai tujuan pendidikan tertentu (Ahid, 2014).

Kurikulum menjadi salah satu komponen penting dalam pendidikan karena secara umum kurikulum memuat deskripsi visi, misi, dan tujuan pendidikan sebuah bangsa. Hal ini memposisikan kurikulum sebagai sentral muatan nilai-nilai yang hendak ditransformasikan kepada peserta didik. Oleh karena itu, kurikulum harus bersifat fleksibel dan dinamis untuk menyesuaikan dengan berbagai perkembangan zaman. Sebab, ketidakmampuan kurikulum dalam mengikuti perkembangan akan menimbulkan ketimpangan-ketimpangan dalam desain kurikulum yang dapat berakibat fatal pada hasil output pendidikan. Paling tidak lulusan pendidikan akan minder atau gagap dalam beradaptasi dan menghadapi kompetisi di era modern yang semakin pesat. Atas dasar pertimbangan itu, kurikulum pendidikan nasional akan selalu mengalami pergeseran dan perubahan seiring dengan dinamika perubahan sosial masyarakat. Dalam hal ini, pemerintah memiliki peranan penting dalam rangka pengembangan kurikulum pendidikan nasional agar mampu menjawab tuntutan perkembangan zaman (Bahri, 2017).

Berdasarkan hasil evaluasi kurikulum yang dilakukan oleh Pusat Kurikulum dan Buku (Puskurbuk) sebagaimana termaktub dalam Rencana Pembangunan Jangka Menengah Nasional (RPJMN) tahun 2010-2014 menunjukkan bahwa perlu ada penataan kembali kurikulum yang diterapkan saat ini. Atas dasar itu, Pemerintah Republik Indonesia pada bulan Juli tahun ajaran 2013-2014 mencanangkan akan memberlakukan Kurikulum 2013 secara terbatas yang merupakan hasil dari penyempurnaan kurikulum sebelumnya, yaitu Kurikulum Tingkat Satuan Pendidikan (KTSP). Penetapan Kurikulum 2013 diharapkan dapat mengatasi kelemahan-kelemahan yang ada pada kurikulum sebelumnya. Hal ini dipertegas oleh Menteri Pendidikan dan Kebudayaan melalui kebijakannya, bahwa Kurikulum 2013 diharapkan dapat menghasilkan manusia indonesia yang produktif, kreatif, inovatif, afektif melalui penguatan sikap, keterampilan, dan pengetahuan yang terintegrasi (PSDMP dan PMP Kemendikbud, 2013). 
Dalam rangka melaksanakan kebijakan tersebut, Kementerian Pendidikan dan Kebudayaan sejak tahun 2013 telah menetapkan implementasi Kurikulum 2013 secara bertahap sampai dengan tahun 2018/2019. Berdasarkan tahapan implementasi yang sudah direncanakan, pada tahun pelajaran 2016/2017, menurut data Kemendikbud, jumlah SMA yang melaksanakan Kurikulum 2013 sebanyak 4.855, sedangkan pada tahun 2017/2018 akan diperbanyak menjadi 60 \% dengan tambahan sebanyak 4.510 SMA yang tersebar di 514 kabupaten/kota dan 34 provinsi. Terhadap 4.510 SMA pelaksana Kurikulum 2013 tersebut, pada tahun anggaran 2017 Direktorat Pembinaan SMA dan Lembaga Penjaminan Mutu Pendidikan (LPMP) memberikan pembinaan dalam bentuk Bimbingan Teknis (Bimtek) dan Pendampingan Implementasi Kurikulum 2013 (Direktorat Pembinaan SMA, 2017).

Adapun di jenjang pendidikan madrasah, implementasi kurikulum 2013 diterapkan secara bertahap mulai tahun pelajaran 2014-2015. Diawali dengan pelaksanaan pada kelas 1 dan 4 MI, kelas 7 MTs, dan kelas 10 MA. Untuk mempersiapkan pelaksanaan tersebut, Dirjen Pendidikan Madrasah Kementerian Agama juga sudah menyelenggarakan workshop dan pelatihan-pelatihan untuk kepala madrasah, guru, dan pengawas madrasah. Selanjutnya, untuk menguatkan implementasi kurikulum 2013, program pelatihan kemudian ditindaklanjuti dengan program pendampingan pada tahun 2015 (Direktorat Pendidikan Madrasah, 2015).

Eksekusi kebijakan implementasi kurikulum 2013 di tingkat lembaga pendidikan itu sendiri sebenarnya tidak berjalan mulus. Salah satu faktor penyebabnya adalah kesiapan internal dari lembaga pendidikan. Meskipun sosialisasi dan pelatihan implementasi kurikulum 2013 sudah banyak dilakukan, namun ternyata sekolah atau madrasah masih banyak yang belum benar-benar siap menerapkan kurikulum 2013. Diakui atau tidak penerapan kurikulum baru tentu butuh proses adaptasi secara bertahap, baik dari aspek perubahan administratif seperti perangkat pembelajaran, model pembelajaran, maupun sistem evaluasi. Kecuali itu, program pelatihan, workshop, dan pendampingan yang sudah ada umumnya hanya dialokasikan bagi para kepala sekolah atau wakil kepala bidang kurikulum, itupun tidak untuk semua sekolah atau madrasah. Sementara untuk guru, rasanya mustahil jika pemerintah memberikan pelatihan semua guru di tanah air. Konseksuensinya, kebanyakan guru cukup kesulitan menerjemahkan kurikulum 2013 dalam pembelajaran.

Di Jepara sendiri, pemberlakuan kurikulum 2013 sebagaimana kebijakan Dirjen Pendidikan Madrasah Kemenag RI sudah direspon oleh madrasah-madrasah swasta. Di tingkat madrasah aliyah, sekitar 18 MA Swasta di Jepara sudah memberlakukan kurikulum 2013. Salah satu madrasah aliyah swasta di Jepara yang telah menerapkan kurikulum 2013 adalah Madrasah Aliyah Walisongo Pecangaan. MA Walisongo Pecangaan merupakan salah satu madrasah swasta yang bernaung di bawah Yayasan Pendidikan Islam Walisongo dan berafiliasi kepada LP Ma'arif NU Jepara. Madrasah ini berlokasi di Jl. Kauman No. 01 Pecangaan Kulon, Kecamatan Pecangaan, Kabupaten 
Jepara. Saat ini MA Walisongo memiliki 32 pendidik dan 8 rombel dengan jumlah peserta didik sebanyak 208.

Namun demikian, implementasi kurikulum 2013 masih jauh dari ketentuan yang berlaku. Hal ini karena sosialisasi dan pelatihan formal yang diadakan oleh pemerintah tidak merata dan tidak berjalan maksimal. Hasil wawancara tim pengabdian dengan Kepala Madrasah, Drs. Santoso, ditemukan bahwa para pendidik di MA Walisongo Pecangaan belum ada yang pernah mengikuti pelatihan atau workshop tentang implementasi Kurikulum 2013 atau perubahan pelaksanaan Kurikulum 2013. Menurutnya, Kementerian Agama secara formal belum pernah mengadakan pelatihan atau workshop tentang implementasi Kurikulum 2013 untuk guru. Memang pernah ada workshop kurikulum 2013 tetapi diadakan oleh Kelompok Kerja Madrasah (KKM) 02 di bawah LP Ma'arif NU Jepara, bukan dari kementerian agama. Itupun hanya untuk kepala madrasah atau yang mewakili, sehingga belum menyentuh para pendidik.

Hingga saat ini para pendidik di MA Walisongo Pecangaan masih belum mampu menerapkan Kurikulum 2013 secara maksimal. Hal ini bisa dilihat dari perangkat pembelajaran, seperti dokumen silabus dan RPP para pendidik yang masih jauh dari konsep dan ketentuan yang telah digariskan dalam kurikulum 2013. Sebenarnya, pihak madrasah sudah mengupayakan untuk mengatasi masalah tersebut dengan membeli CD tutorial penyusunan perangkat pembelajaran Kurikulum 2013. Namun, nyatanya hasilnya tidak maksimal dan tentu saja berbeda dengan hasil dari pelatihan yang dibimbing oleh trainer.

Berdasarkan latar belakang tersebut, tim pengabdi Prodi PAI Unisnu Jepara merasa perlu untuk memberikan solusi atas permasalahan yang dialami oleh MA Walisongo Pecangaan Jepara. Adapun solusi yang ditawarkan oleh tim pengabdi adalah pelatihan dan pendampingan implementasi kurikulum 2013 yang difokuskan pada perangkat pembelajaran. Perangkat pembelajaran menjadi fokus dalam pelatihan dan pendampingan karena menjadi salah satu elemen paling penting dalam proses pembelajaran. Perangkat pembelajaran merupakan pedoman bagi pendidik dalam melaksanakan proses pembelajaran agar terarah dan sesuai dengan tujuan yang telah ditargetkan. Adapun tujuan dari program pengabdian ini adalah untuk meningkatkan kemampuan para guru MA Walisongo Pecangaan dalam menyusun perangkat pembelajaran sesuai ketentuan kurikulum 2013. Sementara luaran yang dihasilkan adalah perangkat pembelajaran meliputi berupa Silabus dan Rencana Pelaksanaan Pembelajaran (RPP).

\section{METODE PELAKSANAAN}

Melihat latar belakang mitra sebagai organisasi non profit dan persoalan yang dihadapi juga bukan permasalahan ekonomi tentu saja pendekatan yang digunakan dalam memecahkan masalah bukanlah pendekatan yang bersifat materiil atau ekonomis. Karenanya, dalam pelaksanaan program pengabdian ini, tim pengabdi 
memilih menggunakan pendekatan transformatif, yaitu memberikan wawasan, pengetahuan, dan nilai untuk merubah pandangan, pemikiran, sikap dan tingkah laku mitra menuju kemandirian personal. Perubahan ini dipandang penting karena, para guru MA Walisongo Pecangaan Jepara masih belum memahami betul konsep kurikulum 2013 yang lebih menekankan student centered dan memberikan ruang yang cukup luas untuk ranah afektif peserta didik. Para guru masih terjebak dalam konsep dan pola pikir KTSP yang lebih condong kepada aspek kognitif, sehingga sulit bagi mereka memahami konsep Kurikulum 2013 tanpa ada perubahan paradigma berpikir secara mendasar.

Untuk mencapai mencapai target yang telah direncanakan di atas, tim pengabdian menentukan beberapa metode pelaksanaan, antara lain: Pertama, pelatihan atau disebut juga training. Pelatihan sebagaimana didefinisikan oleh Rowley dan Jackson adalah cara untuk memperoleh pengetahuan dan keahlian sebagai hasil dari pembelajaran tentang keahlian praktis dan pengetahuan yang berhubungan dengan kompetensi spesifik yang berguna. Pelatihan merupakan konsep manajemen sumber daya manusia terbatas melalui aktifitas pemberian instruksi-instruksi khusus yang direncanakan atau melatih keahlian tertentu (Rowley \& Jackson, 2012).

Dalam kegiatan ini, pelatihan direncanakan selama dua hari penuh. Pelatihan dimaksudkan untuk memberikan pengetahuan teoritis maupun praktis terkait dengan perangkat pembelajaran kurikulum 2013. Untuk menyampaikan materi-materi tersebut, tim pengabdian memilih menggunakan metode demonstration and example, yaitu metode pelatihan yang dilakukan dengan cara peragaan dan penjelasan bagaimana caracara melakukan suatu pekerjaan melalui contoh atau percobaan yang didemonstrasikan. Motode ini meniscayakan para peserta terlibat aktif dalam pelatihan di bawah bimbingan dan fasilitasi pelatih.

Metode kedua adalah pendampingan. Pendampingan merupakan kegiatan pemberian fasilitas oleh pendamping kepada klien dalam mengidentifikasi kebutuhan dan memecahkan masalah serta mendorong tumbuhnya inisiatif dalam pengambilan keputusan sehingga dapat mewujudkan kemandirian klien secara berkelanjutan. Pendampingan sendiri bisa dilakukan dengan berbagai cara seperti penyampaian informasi, control, pengawasan, konsultasi, coaching, problem solving, dan lain-lain (Departemen Sosial RI, 2005).

Dalam hal ini, Bentuk pendampingan yang dilakukan ialah dengan cara pertemuan rutin secara berkala antara tim pengabdian dengan para guru. Kegiatan pendampingan ini bertujuan untuk mengontrol sejauh mana perkembangan penyusunan perangkat pembelajaran kurikulum 2013 yang dilakukan oleh para guru. Di samping itu, kegiatan ini juga merupakan wadah bagi para guru untuk mendiskusikan kemajuan perangkat pembelajaran dan pencarian solusi atas hambatan-hambatan yang dihadapi mitra dalam menyusun kurikulum 2013. Sekurang-kurangnya, pendampingan ini dilaksanakan minimal 4 kali dan atau sampai perangkat pembelajaran yang direncanakan telah tersusun sesuai ketentuan kurikulum 2013.

Langkah terakhir setelah pelatihan dan pendampingan adalah evaluasi. Evaluasi dilakukan untuk mengetahui hasil kinerja para guru dalam menyusun perangkat pembelajaran kurkulum 2013. Evaluasi di sini ditekankan pada produk berupa draft 
perangkat pembelajaran kurikulum 2013 yang telah disusun oleh para guru MA Walisongo Pecangaan, apakah sesuai dengan ketentuan kurikulum 2013 ataukah tidak.

\section{HASIL DAN PEMBAHASAN}

Sebelum pelaksanaan program, hal pertama yang dilakukan oleh tim adalah mempersiapkan program dengan perijinan kemudian dilanjutkan dengan analisis situasi mitra. Analisis situasi dilakukan dengan metode interview dan Focus Group Discussion (FGD) untuk mengetahui kondisi terkini dari mitra program. Dalam hal ini, tim pengabdian melakukan wawancara dengan kepala dan diskusi kecil beberapa guru MA Walisongo Pecangaan. Hasilnya diketahui bahwa MA Walisongo telah dengan menerapkan kurikulum 2013 semenjak tahun 2014 secara terbatas pada kelas 10. Hal ini merupakan respon dari kebijakan Dirjen Pendidikan Madrasah Kemenag RI tentang penerapan kurikulum 2013 secara bertahap. Sayangnya, penerapan K-13 tersebut tidak dibarengi dengan adanya fasilitasi pelatihan dan pendampingan terhadap para guru pengampu mata pelajaran. Semua guru di MA Walisongo, kecuali Kepala MA dan Waka Kurikulum, belum pernah mengikuti pelatihan tentang kurikulum 2013. Konsekuensinya, penerapan K-13 di MA Walisongo, khususnya pada aspek pembelajaran, belum berjalan secara maksimal.

Langkah selanjutnya setelah analisis situasi adalah perekutran peserta program. Dalam hal ini, semua guru di MA Walisongo, termasuk Kepala Madrasah dan para wakilnya, sejumlah 32 orang dimasukkan menjadi peserta program. Selain karena alasan menghindari kecemburuan sosial, hal ini dimaksudkan agar manfaat program bisa dirasakan secara merata oleh semua guru sehingga diharapkan semua guru mampu menerapkan kurikulum 2013 dalam pembelajaran yang diampu. Namun demikian, tim pengabdian tetap menyodorkan kontrak atau kesepakatan dengan peserta bahwa setiap peserta harus membawa laptop sendiri-sendiri dan sanggup mengikuti semua sesi pelatihan. Setelah perekrutan tersebut, langkah terakhir sebelum program dijalankan adalah penyusunan materi pelatihan dengan merujuk pada peraturan menteri dan buku-buku panduan kurikulum 2013 keluaran Kementerian Pendidikan dan Kementerian Agama.

Selanjutnya, program pengabdian dilanjutkan dengan pelatihan penyusunan perangkat pembelajaran kurikulum 2013 bagi guru MA Walisongo Pecangaan. Kegiatan pelatihan ini dilaksanakan selama dua hari, yakni pada tanggal 6 dan 7 April 2018 bertempat di ruang rapat MA Walisongo. Kegiatan ini diikuti oleh seluruh pimpinan dan guru MA Walisongo Pecangaan yang kesemunya berjumlah 32 orang. Dari pelatihan ini diharapkan para peserta mampu memahami konsep kurikulum 2013 beserta perangkat pembelajarannya, baik secara teoritis maupun praktis meliputi konsep kurikulum 2013, Silabus \& pemetaan KI-KD, penyusunan RPP, dan pembelajaran saintifik.

Hari pertama pelatihan, yakni hari Sabtu 6 April 2018 diawali dengan opening ceremony dan pembukaan kegiatan secara simbolis oleh Dekan Fakultas Tarbiyah dan Ilmu Keguruan UNISNU Jepara. Dalam acara opening ini, Drs. Santoso, Kepala MA Walisongo yang diberikan waktu untuk menyampaikan sambutan merespon positif 
program pengabdian ini. Ia menyampaikan bahwa pelatihan penyusunan perangkat pembelajaran kurikulum 2013 menjadi kegiatan penting yang sangat membantu untuk meningkatkan sumber daya manusia (SDM) para pendidik MA Walisongo.

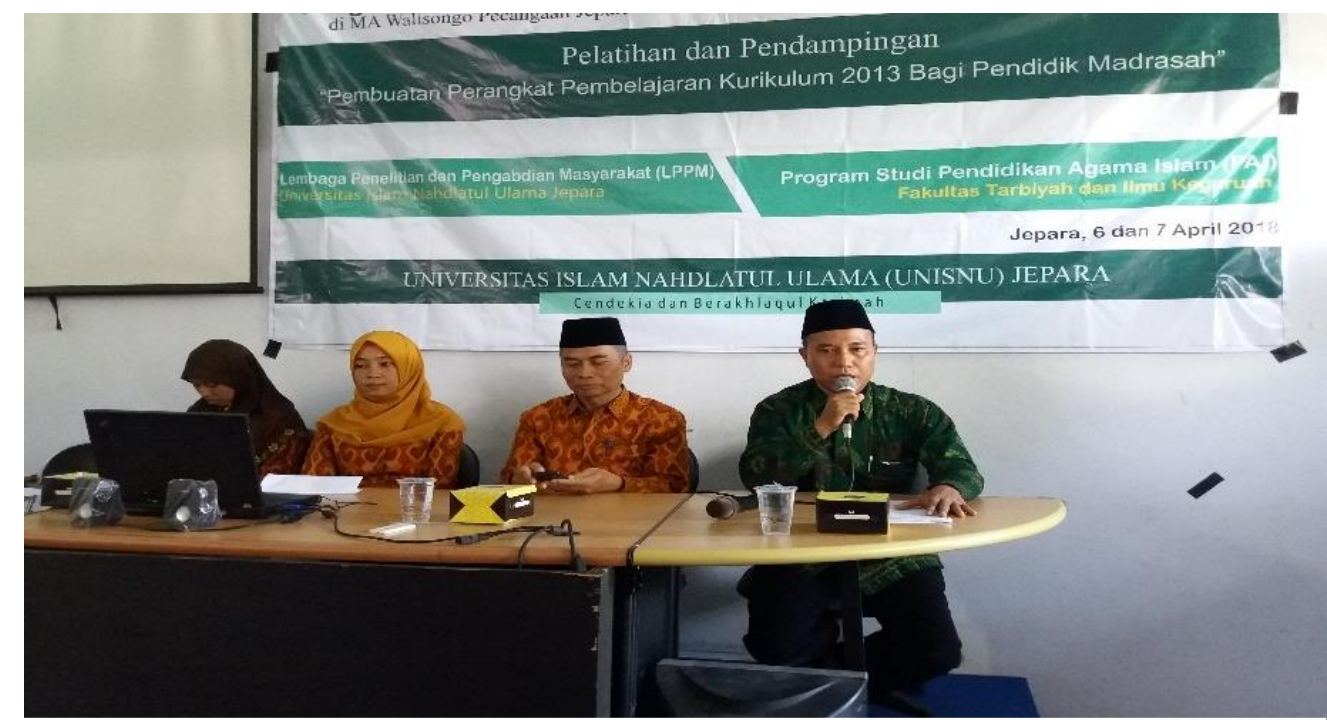

Gambar 1. Opening Ceremony Sebelum Pelatihan

Kegiatan dilanjutkan dengan penyampaian materi pelatihan. Sesi pertama mengangkat materi tentang Konsep Kurikulum 2013, Rasional dan Elemen Perubahan Kurikulum. Materi ini dimaksudkan untuk secara teoritis memberikan wawasan tentang kurikulum 2013 secara teoritis meliputi unsur-unsur, karakteristik, perbedaan, dan perubahan. Pada sesi ini, Mahalli, sebagai pemateri juga memberikan motivasi dan wawasan-wawasan baru dalam pembelajaran perspektif teori-teori modern serta kaitannya dengan kurikulum 2013 kepada para peserta untuk mengubah pola pikir para peserta dari paradigma kurikulum lama menuju kurikulum baru. Sesi ini berlangsung sekitar 2 jam mulai pukul 09.00 hingga 12.00 WIB.

Pada sesi kedua disampaikan materi tentang "Silabus dan Pemetaan KI-KD". Materi ini penting untuk disampaikan kepada peserta agar memahami peta kompetensi di kurikulum 2013 yang agak berbeda dengan kurikulum sebelumnya. Disampaikan pula ranah-ranah kompetensi sesuai ranah psikologis dalam pembelajaran berikut indikator-indikator dan kata kerja operasional yang bisa digunakan. Pada sesi ini peserta juga diajak untuk melakukan analisis terhadap KIKD sesuai dengan kompetensi yang ditargetkan di kurikulum 2013 meliputi pengetahuan, keterampilan, sikap spiritual, dan sikap sosial. Dalam hal ini, yang bertindak sebagai pemateri adalah Azzah Noor Laila.

Pada hari kedua, pelatihan difokuskan pada penyusunan rencana pelaksanaan pembelajaran (RPP) sesuai format kurikulum 2013. Ada dua materi yang disampaikan pada hari kedua ini. Pertama, unsur-unsur RPP meliputi identitas mata pelajaran, KI, KD dan indikator, tujuan pembelajaran, langkah-langkah pembelajaran, strategi dan metode pembelajaran, media pembelajaran, materi pembelajaran, dan evaluasi pembelajaran. Dalam hal ini, Khalimatus Sa'diyah sebagai pemateri selain 
menjabarkan unsur-unsur yang harus ada dalam RPP juga menyampaikan kriteriakriteria yang harus dipenuhi oleh setiap unsur. Sebagai contoh dalam menyusun tujuan pembelajaran harus memenuhi unsur-unsur berikut, yakni Audiens, Behaviour, Condition, dan Degree atau biasa disingkat dengan ABCD.

Setelah sesi pertama, pelatihan dilanjutkan dengan simulasi penyusunan silabus dan RPP. Dipandu oleh Fathur Rohman, dalam simulasi ini peserta dibagi menjadi empat kelompok sesuai dengan rumpun keilmuan yang diampu oleh guru. Empat kelompok tersebut antara lain: Pertama, kelompok ilmu eksak untuk guru pengampu mata pelajaran Matematika, Kimia, Biologi, dan Fisika. Kedua, kelompok ilmu sosial untuk mata pelajaran Ekonomi, Sejarah, Sosiologi, Antropologi, dan Seni Budaya. Ketiga, kelompok bahasa untuk guru pengampu mata pelajaran Bahasa Indonesia, Inggris, dan Arab. Keempat, kelompok mata pelajaran PAI untuk mata pelajaran PAI dan muatan lokal agama. Peserta secara berkelompok diberi waktu untuk berdiskusi dan bekerja secara kelompok untuk menysusun perencanaan pembelajaran dengan sesuai materi yang telah disampaikan sebelumnya. Di akhir simulasi sesi, setiap kelompok wajib mempresentasikan hasil kerjanya didepan kelas dengan diwakili oleh salah satu anggota dan diberi waktu untuk tanya jawab tentang perencanaan pembelajaran yang telah disusun bersama.

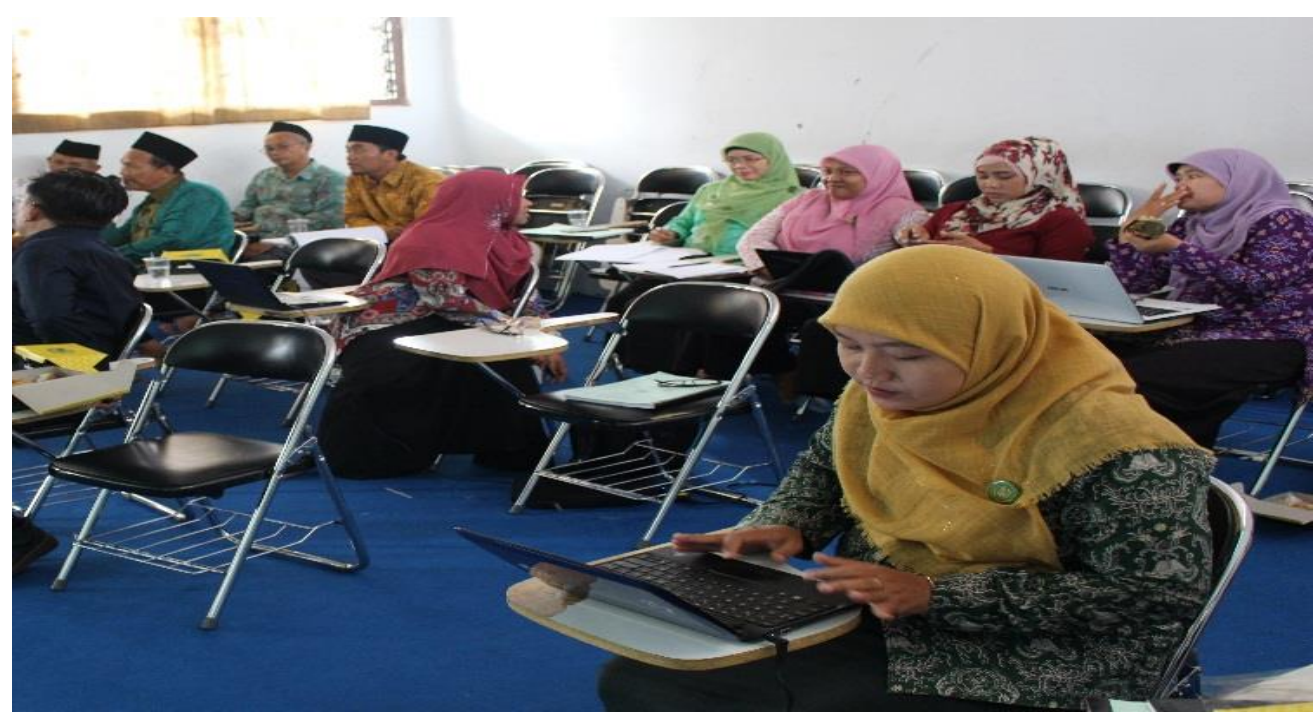

Gambar 2. Praktik Menyusun Silabus dan Rencana Pelaksanaan Pembelajaran (RPP)

Setelah kegiatan pelatihan selama dua hari, peserta diberi waktu kurang lebih empat minggu untuk menyusun perangkat pembelajaran secara individual. Dalam rentang waktu tersebut, tim pengabdian mengadakan kegiatan pendampingan terhadap proses penyusunan perangkat pembelajaran. Pendampingan ini dilakukan dengan cara tim pengabdian mengunjungi lokasi mitra MA Walisongo Pecangaan untuk mengecek kemajuan penyusuanan perangkat pembelajaran dan memberikan arahan sekaligus memecahkan masalah yang dihadapi para guru dalam proses penyuusunan. Para peserta diberikan kesempatan untuk menyampaikan kemajuan 
penyusunan perangkat pembelajaran, kemudian tim pengabdian memberikan masukan, koreksi, dan pembenahan hasil kinerja tersebut.

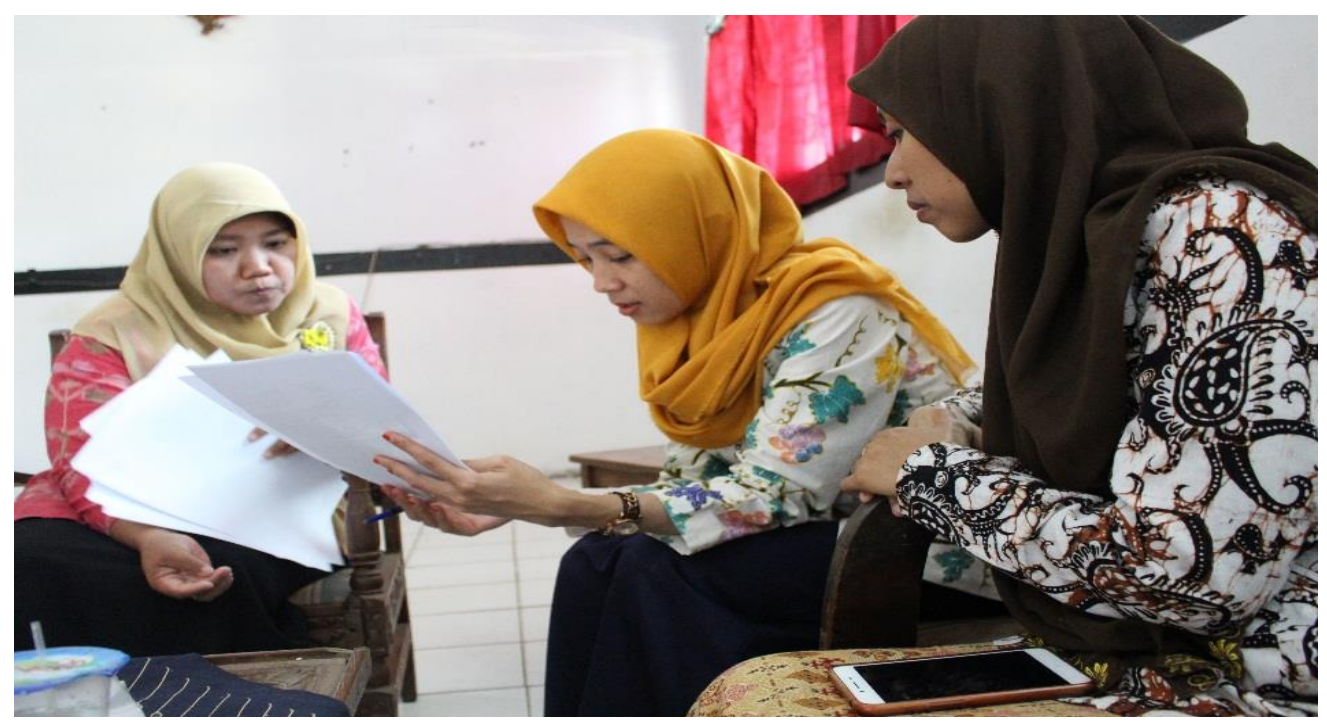

Gambar 3. Pendampingan penyusunan perangkat pembelajaran kurikulum 2013

Program pendampingan penyusunan perangkat pembelajaran kurikulum 2013 diakhiri dengan evaluasi. Evaluasi dilakukan dengan cara mengecek draft perangkat pembelajaran kurikulum 2013 apakah sesuai dengan ketentuan atau tidak dan dengan Focus Group Discussion (FGD) dengan para guru MA Walisongo Pecangaan tentang seberapa jauh pemahaman mereka tentang kurikulum 2013. Adapun hasil dari program pengabdian ini adalah draft perangkat pembelajaran berupa silabus dan RPP semua mata pelajaran yang diajarkan di MA Walisongo Pecangaan meliputi mata pelajaran umum, mata pelajaran pendidikan agama Islam, dan mata pelajaran muatan lokal. Draft perangkat pembelajaran ini selanjutnya akan dijadikan acuan resmi madrasah untuk pembelajaran berdasarkan kurikulum 2013.

\section{SIMPULAN}

Program pengabdian masyarakat tentang penyusunan perangkat pembelajaran kurikulum 2013 ini diawali dengan kegiatan pelatihan dalam dua tahap. Pertama, tahap penyampaian materi meliputi kajian teoritis kurikulum 2013, silabus serta pemetaan KIKD, dan langkah penyusunan RPP. Kedua, tahap simulasi atau praktek. Peserta secara berkelompok praktek menyusun silabus dan RPP sesuai format kurikulum 2013. Kemudian dilanjutkan pendampingan terhadap semua guru dalam penyusunan perangkat pembelajaran secara individual. Hasilnya semua guru MA Walisongo Pecangaan Jepara dapat menyusun draft perangkat pembelajaran sesuai format kurikulum 2013. 


\section{UCAPAN TERIMA KASIH}

Terima kasih sebesar-besarnya dari tim pengabdian Prodi PAI Fakultas Tarbiyah dan Ilmu Keguruan Unisnu Jepara disampaikan Lembaga Penelitian dan Pengabdian Masyarakat (LPPM) Universitas Islam Nahdlatul Ulama Jepara yang telah memfasilitasi kegiatan pengabdian kepada masyarakat di MA Walisongo Pecangaan Jepara. Terima kasih pula disampaikan kepada keluarga besar MA Walisongo Pecangaan Jepara, khususnya Kepala Madarasah yang merespon program ini dengan baik dan kepada para guru yang sangat antusias mengikuti dan sanggup bekerja keras untuk mensukseskan kegiatan ini.

\section{DAFTAR RUJUKAN}

Ahid, N. (2014). Konsep dan Teori Kurikulum dalam Dunia Pendidikan. ISLAMICA: Jurnal Studi Keislaman, 1(1), 12-29. https://doi.org/10.15642/islamica.2006.1.1.12-29.

Bahri, S. (2017). Pengembangan Kurikulum, Dasar dan Tujuannya. Jurnal Ilmiah Islam Futura, 11(1), 15-34. https://doi.org/10.22373/jiif.v11i1.61.

Departemen Sosial RI. (2005). Pedoman Umum Pendampingan Masyarakat Miskin. Jakarta: Depsos RI.

Direktorat Pembinaan SMA. (2017). Panduan Bimbingan Teknis dan Pendampingan Implementasi Kurikulum 2013 SMA Tahun 2017. Jakarta: Direktorat Pembinaan SMA, Direktorat Jenderal Pendidikan Dasar dan Menengah.

Direktorat Pendidikan Madrasah. (2015). Petunjuk Teknis Program Pendampingan Implementasi Kurikulum 2013 di Madrasah. Jakarta: Dirjen Pendis Kemenag RI.

PSDMP dan PMP Kemendikbud. (2013). Pedoman Kegiatan Pendampingan Implementasi Kurikulum 2013 bagi Pengawas Sekolah, Kepala Sekolah, dan Guru Inti. Jakarta: Pusbang Tendik Kemendikbud.

Rowley, C., \& Jackson, K. (2012). Manajemen Sumber Daya Manusia; The Key Concepts terj. Elviyola Pawan. Jakarta: Rajawali Pers. 